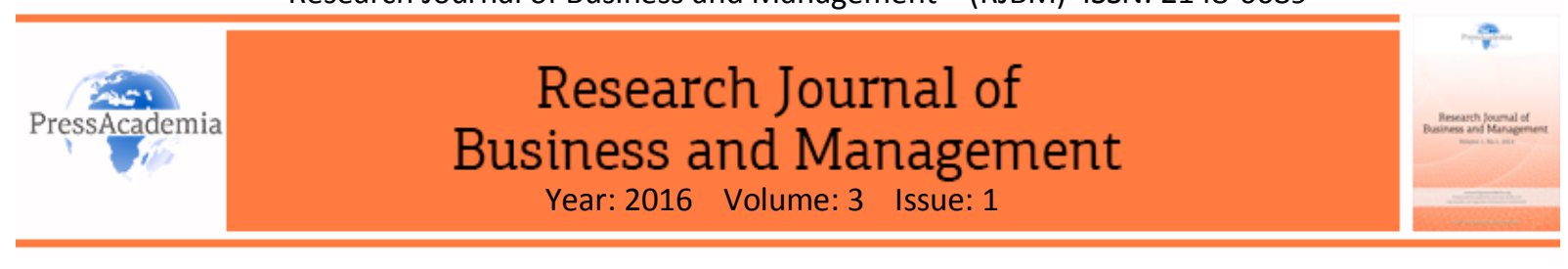

\title{
EFFECTS OF PATERNALISTIC LEADERSHIP ON ORGANIZATIONAL IDENTIFICATION: MEDIATING ROLE OF TRUST IN LEADER
}

\section{DOI: 10.17261/Pressacademia.2016116546}

\author{
Nurcan Hakan Ciraklar ${ }^{1}$, Zeki Ucar ${ }^{2}$, Oytun Boran Sezgin ${ }^{3}$ \\ ${ }^{1}$ Dokuz Eylül Üniversitesi. n.ciraklar@deu.edu.tr \\ ${ }^{2}$ Bitlis Eren Üniversitesi. zucar@beu.edu.tr \\ ${ }^{3}$ Dokuz Eylül Üniversitesi. boran.sezgin@deu.edu.tr
}

\begin{abstract}
Leadership as a topic holds an important place in literature in the area of organization and management. Despite the research on managerial approaches and practices based on the cultural characteristics of western societies is abundant, the research reflecting cultural characteristics of eastern societies in the same field is scarce. On the other hand, recent research has frequently demonstrated that the leadership model based on paternalism phenomenon which reflects the dominant cultural characteristics of eastern societies is highly effective in those societies (Pellegrini et al., 2010). As substantial amount of studies show paternalistic leadership phenomenon is also a positive cultural value in our country. It is important to investigate the effects of this phenomenon on different affective and cognitive mechanisms that lead to positive employee behaviours. Regarding this, the purpose of this study is to examine the mediating role of trust in the leader on the effect of paternalistic leadership on organizational identification. The data is collected from 148 employees who work in three different industries in izmir. The path analysis findings indicated that trust in leader mediates the relationship of benevolent leadership and identification. These findings compatible with hypothetical model.
\end{abstract}

Keywords: Paternalism, paternalistic leadership, trust in leader, organizational identification, SEM.

JEL Classification: M10, D23, M50

\section{PATERNALIST LIDERLIĞiN ÖRGÜTSEL ÖZDEŞLEŞME ÜZERINE ETKISI: LIDERE GÜVENIN ARACILIK ROLÜ}

\section{ÖZET}

Örgüt ve yönetim araştırmalarının temel çalışma alanlarından birini teşkil eden liderlik araştırmaları alan yazında önemli bir yer tutmaktadır. Ancak, batı toplumlarının kültürel özelliklerine dayalı etik bağlamdaki yönetsel anlayış ve uygulamalara ilişkin araştırmalar yaygın olmasına karşın, doğu toplumlarının kültürel özelliklerini yansıtan emik araştırmalar oldukça yetersizdir. Bununla birlikte son yıllardaki araştırmalarda, doğu toplumlarının baskın kültürel özelliğini yansıtan paternalizm olgusuna dayalı bir liderlik modelinin bu toplumlarda daha etkili olduğu sıklıkla ifade edilmektedir. Ülkemizde de olumlu bir kültürel değeri yansıttığı bir çok araştırmada ortaya konan paternalist liderlik olgusunun, işgörenleri olumlu iş davranışları sergilemeye yönlendiren farklı duyuşsal, bilişsel ve tutumsal mekanizmaları ne yönde etkilediğinin araştırıması bu açıdan önem arz etmektedir. Bu bağlamda çalışma, paternalist liderliğin örgütsel özdeşleşme üzerindeki etkisinde lidere güvenin aracılık rolünü incelemeyi amaçlamaktadır. Araştırmada veriler, İzmir ilindeki üç farklı endüstrideki 148 çalışan üzerinden kolayda örnekleme yöntemi ile toplanmıştır. Araştırma amacı doğrultusunda, path (yol) analizi bulguları, paternalist liderlik boyutlarından yardımseverlik ile özdeşleşme ilişkisinde varsayımlanan modele uygun olarak lidere güvenin aracılık rolü olduğunu göstermektedir.

Anahtar Kelimeler: Paternalizm, paternalist liderlik, lidere güven, örgütsel özdeşleşme, YEM.

JEL Sınıflandırması: M10, D23, M50 


\section{GiRiş}

Etkili liderlik özelliklerinin belirlenmesi ve kavramı tanımlama çabaları, uzun yıllardan beri tartışma konusu olmuştur. Özellikle, Hofstede'in (1980) farklı toplumların kültürel özelliklerini belirlemeye yönelik çalışması ile birlikte, liderlik araştırmalarının da farklı kültürel bağlamlar içine sürüklenmesini gündeme getirmiştir. Ancak mevcut bilgi ve anlayışların etkili liderlik özeliklerini kültür bağlamında açıklamalarının sınırlı kaldığı görülmüştür (Pellegrini ve Scandura, 2008: 566). Buradan hareketle, liderlik araştırmalarında farklı kültürel özellikleri de dikkate alan yaklaşımların geliştirilmeye başlandığı ve etkili liderlik özellikleri ile davranışlarının belirlemesine yönelik araştırmaların yoğunluk kazandığı gözlemlenmektedir. Bu yaklaşımlardan biri, özellikle doğu toplumlarının kültürel özelliklerini yansıtan paternalist liderlik anlayışıdır. Paternalist liderlik, genellikle bir inanç sistemi olarak, babacan yardımseverlik ve ahlaki bütünlük ile birleştirilen yüksek disiplin ve otorite şeklinde tanımlanmaktadır (Farh ve Cheng, 2000: 84). Bu anlayışa, Türkiye'nin de içinde bulunduğu Ortadoğu, Doğu Asya ve Latin Amerika gibi ülkeler olumlu bakarlarken, batı toplumları olguyu sadece otoriter liderlik çerçevesinde değerlendirdikleri için olumsuz yaklaşmaktadırlar (Aycan, 2006; Niu vd., 2009). Paternalist liderlikte, lider üyelerinden yüksek derecede bağlılık ve sadakat beklerken; izleyiciler ise, liderlerinden yardımsever, ahlaki ve güven veren bir duruş ortaya koymasını beklemektedirler. Paternalist lider-üye etkileşimi içerisinde işgörenlerin olumlu tutum ve davranışlar sergilemeleri, bireysel beklentilerinin ne derecede karşılanmış olduğuna ve liderlerini ne şekilde algıladıklarına bağlıdır. Buna bağlı olarak, onları olumlu iş davranışları sergilemeye yönlendiren farklı duyuşsal, bilişsel ve tutumsal hangi mekanizmaların harekete geçirdiğinin belirlenmesi önem arz etmektedir. Bu karşılıklı beklentiler temelinde işgörenler, bir yandan lidere karşı bir aile üyesi gibi güven duymayı beklerken diğer yandan lider, izleyicilerinden itaat, bağlılık göstermelerini beklemektedir. Bu beklentilerin karşılanması sonucu, izleyicilerin hem liderine ve hem de kurumuna duygusal yönden bağlılıklarının güçlenmesi ve kurum kimliği ile özdeşleşmeleri olasılığı doğabilecektir. İlgili alan yazında paternalist lider-üye etkileşim sürecinde karşılıklı beklentileri dikkate alan sınırlı sayıda araştırma olduğu görülmektedir. Yazındaki boşluğu gidermek üzere bu çalışma, paternalist liderlik ve örgütsel özdeşleşme ilişkisinde lidere güvenin aracılık rolünü incelemeyi amaçlamaktadır.

Bu amaç doğrultusunda, aşağıda öncelikle çalışmanın kavramsal ve kuramsal yapısına ilişkin literatür incelenmiş ve bir yapısal eşitlik modeli oluşturulmuştur. Daha sonra model, uygun istatistiksel tekniklerle analiz edilmiş, elde edilen bulgular ışığında sonuç ve öneriler getirilmiştir.

\section{LITERATÜR TARAMASI}

\subsection{Paternalist Liderlik}

Paternalizm teriminin kökeni Latince "pater" kelimesine dayanmakta ve Türkçe karşılığı "baba” anlamına gelmektedir (http://www.etimolojiturkce.com). Paternalizm, kaynağını kültürden (Erben ve Ökten, 2014: 106) ve ataerkillikten (Yeh vd., 2008: 85) almaktadır. Özellikle, aile birimi içerisinde ataerkillik ve aynı soydan gelenler üzerine güçlü bir şekilde vurgu yapan gelenekçi ailesel değerler, paternalizmin temel destekleyicisi olarak değerlendirilmektedir (Aycan, 2006: 446). Bu yönü ile paternalizm, bireyin üzerinde otorite sahibi olduğu diğer kişileri bir baba gibi koruma ve bu koruma karşılığında onlardan çocuklarıymış gibi sadakat ve itaat beklediği (Paşa vd., 2001; Aycan, 2006; Gelfand vd., 2007) bir süreç (Köksal, 2011a: 159), ilişkisel bir inanç sistemi ve bir mübadele ilişkisi (Aycan vd., 2000; Kabasakal ve Bodur, 2001) olarak tanımlanabilir.

Bilimsel yazarların paternalizmin kökeninini açıklamaya ilişkin olarak iki farklı bakış açısını araştırmalara konu ettikleri görülmektedir. Bazı yazarlar, (Pellegrini ve Scandura, 2008) Weber'in Bürokratik yapı içerisinde ele almış olduğu otorite ve geleneksel yetki kavramlarına vurgu yaparak batı bakış açısını yansıtırlarken, diğerleri (Niu vd., 2009; Cheng vd., 2004; Yeh vd., 2008) ise (genellikle uzakdoğu kökenli) Konfüçyüs'ün öğretilerinde sıkça kullanılan otorite, itaat ve ahlak kavramlarına değinmektedir.

Daha çok toplulukçu kültürlerde karşılaşılan ve bir inanç sistemini temsil eden paternalist anlayış içerisinde, paternalist liderlerin çalışanlarının özel hayatı içerisinde bir figür olması ve onların yerine karar alması arzu edilen bir durum iken, bireyci toplumlarda bu durum özel hayatın ihlali olarak değerlendirilmektedir (Aycan, 2006: 450). Kültürler arası karşılaştırmaların yapıldığı araştırmalarda (örn. Aycan vd., 2000), kültürden kültüre farklı algılandığı ortaya konan paternalizm olgusu, özellikle doğu kültürlerinde etkili bir yönetim tarzı olarak 
değerlendirilirken, batılı toplumlarda arzu edilmeyen bir yönetim tarzını yansıtmaktadır (Pellegrini vd., 2010: 392). Daha önce belirtildiği gibi paternalizm yardımseverliğe vurgu yapmasından ötürü otoriterlikten farkıılışmasına karşın, batı bakış açısı paternalizmi, sadece otoriterlikle eş anlamlı tutarak olumsuz bir durum olarak değerlendirmektedir (Aycan, 2006; Farh ve Cheng, 2000; Niu vd., 2009; Cheng vd., 2004; Pellegrini ve Scandura, 2008; Paşa vd., 2001; Aycan, 2006). Oysa, güç mesafesi ve toplulukçu kültür değerleri yüksek olan Doğu Asya, Orta Doğu ve Latin Amerika ülkelerinde paternalizm, karşılıklı inanç sistemini yansıtan kültürel bir değer sistemi olarak, olumlu bir özellik olarak kabul görmektedir (Aycan, 2006: 446; Niu vd., 2009: 32). Özellikle, Çin başta olmak üzere doğu toplumlarının kültüründe paternalizm üzerinde, Konfüçyüs ilkeleri, lider ve izleyicileri arasındaki dikey ilişkinin merkeziyetçiliğinin önemli etkileri vardır. Aycan vd.'nin (2000) on ülke üzerinde gerçekleştirmiş oldukları kültürler arası karşılaştırmada, bireycilik yönü öne çıkan ülkelerin düşük paternalist özellikler sergiledikleri görülürken; toplulukçu yönü öne çıkan ülkelerde ise, yüksek paternalist özellikler gözlemlenmektedir. Bununla birlikte Aycan (2006), gelişmiş ve endüstrileşmiş batılı toplumların paternalizme bakış açılarında değişme görüldüğünü ve özellikle son dönemlerde paternalizmi sosyal ve örgütsel sorunlara uygun bir çözüm olarak düşündüklerini belirtmektedir.

Paternalist liderliğe ilişkin araştırmaların çıkış noktası olarak, Silin (1960)'in doktora çalışması gösterilmektedir. Silin (1960) Tayvan' da büyük ölçekli iş̧letmeler üzerinde yaptığı çalışmasında, batılı liderlik tarzlarıyla karşılaştırıldığında, ahlaki standartlar ve otorite gücü yönüyle paternalist liderliğin, batılı liderlik tarzlarından farklılaşan bir liderlik anlayışı olduğunu ortaya çıkarmıştır (Yeh vd., 2008: 85).

Bir liderlik tarzı olarak paternalizm, babacan yardımseverlik ve ahlaki bütünlük ile birleștirilen yüksek disiplin ve otorite olarak tanımlanmaktadır (Farh ve Cheng, 2000: 84). Uh-Bien ve Maslyn (2005)'in ifadesiyle, ilişkisel ve karşııkı bir inancı tanımlayan paternalizm, bir tarafta otoritesi altındakini koruyan, ona yardım eden, önemseyen ve yardım eden bir otorite profili ortaya koyarken, diğer tarafta ise otoritenin kendilerine ilişkin davranışlarını sadakat, saygı ve itaatle buluşturan bir ast profili çizmektedir (Aktaran: Köksal, 2011b: 103). Gelfand vd., (2007) paternalist liderliği, hiyerarşik bir ilişki içinde liderin astlarının özel ve mesleki yaşantılarına ilişkin olarak onlara tıpkı bir ebeveyn gibi rehberlik etmesi ve karşılığında onlardan bağılık ve itaat beklemesi olarak tanımlamaktadır. Bu yönüyle, otoritenin göstermiş olduğu ilgi ve bu ilginin karşılığında saygı ve itaat beklentisi ile bütünleşen paternalizm olgusu (Pellegrini ve Scandura, 2008: 567), batı bakış açısının tanımladığı hiyerarşik ilişki düzeninin ötesinde çok daha fazla karmaşıklık içeren (Börekçi, 2009: 104) karşııklı bir değişim süreci olarak (Aycan ve Kabasakal, 2006: 474) ilişkisel bir inanç sistemini yansıtmaktadır.

Günümüzde yeni paternalist liderlik olarak tanımlanan anlayış otoriter, yardımsever ve ahlaki liderlik olmak üzere üç boyutlu ele alınmaktadır (Farh ve Cheng,2000; Niu vd. 2009; Cheng vd. 2004; Wu vd. 2012). Paternalist liderler, astları üzerinde güçlü otoritelerini vurgulamak için kontrol stratejileri kullanırlar ve sıkı bir disipline vurgu yaparak otoriter yönlerini ortaya koyarlar. Yardımseverlik boyutu ile astlarının mutluluğu için özel bir ilgi gösterirler. Ahlaki boyut ise, paternalist liderlerin davranışlarında erdem ve öz disipline sahip olması, bencilliğin yer almaması gerektiğini vurgulamaktadır (Niu vd.,2009: 32; Cheng vd., 2004: 91).

\subsection{Lidere Güven}

İnsanların birlikte çalışabilmesi dayanışmayı içermekte ve bu sayede kişisel ve örgütsel hedeflere ulaşabilme başkalarına bağı hale gelmektedir (Mayer vd. 1995: 710). Driscoll (1978), etkileşim halindeki bireylerin davranışlarını belirleyen en kritik değişkenin güven olduğunu belirterek, birey davranışlarının başkalarından yalıtılmış ya da bağımsız olmasını beklemenin olası olmadığını ifade etmektedir. Güven, en yalın haliyle bir olayın sonuçlarına ilişkin bireyin iyimser beklentisidir (Hosmer, 1995: 381). Güven kavramında, güvenilen ve güvenen olmak üzere iki taraf söz konusudur (Mayer vd., 1995: 712). Buna göre güven, güvenen tarafın kendisi için önem arz ettiği durumlarda, güvenilen tarafın kontrol ya da gözetim altında tutamadığı faaliyetlerine karşı savunmasız kalması konusunda gönüllülük göstermesidir. Ilişkilerde yüksek seviyedeki güven, bireylerin olumlu tutum geliştirmelerinde ve işbirliğinde bir artışa yol açmakta, aynı zamanda, iş̧yerindeki davranışlarını geliştirmelerine zemin hazırlamaktadır (Dirks ve Ferrin, 2001: 451). Güven, örgütsel ilişkileri geliştiren bir etmen (Bunker vd., 2004: 413), örgütün istikrarlı bir geleceğe sahip olması ve örgüt üyelerinin iyi olma hali (Cook ve Wall, 1980: 39) bakımlarından da önemli bir kavramdır. Culbert ve McDonough (1986) güvene dayalı ilişkilerin, yöneticiler açısından etkili ve güçlü bir araç olduğunu iddia etmekte ve bu temeldeki ilişkiler sayesinde mükemmel olmayan planların bile başarılı olabileceğini bildirmektedir. 
Özellikle 90'I yılardan sonra güven olgusu, yoğun bir şekilde araştırmalara konu olmuştur (Bunker vd., 2004: 413). Yönetim ve örgüt yazınında güven kavramı; iş arkadaşlarına güven, yönetime güven, amire güven, kurumsal güven gibi çok çeşitli boyutlar ile incelenmiştir (McCauley ve Kuhnert, 1992: 261). Lidere güven takım performansı (Dirks, 2000), genel performans (Rich, 1997), görevin içselleştirilmesi ve görevi başarabilmek için çabalama (Oldham, 1975),örgütsel bağlılık (Podsakoff vd., 1996), tatmin (Rich, 1997), örgütsel vatandaşlık (Pilai vd., 1999) ve örgütsel ses (Gao vd., 2011) gibi değişkenlerle ilişki olması nedeniyle önem kazanmıştır. Yöneticilere/lidere duyulan güvenin hangi yönetici/lider davranışları ile şekillendiği (Whitener vd., 1998; Burke vd., 2007) yönetim yazınında oldukça ilgi çeken bir konu haline gelmiştir. Lidere güven konusundaki çalışmalardaki artış konunun derinleşmesine ve paradigmanın güçlenmesine yol açmıştır. Karar vericiye olan güven, bir yandan örgütteki memnuniyet durumunu arttıırken, diğer yandan, kararlara katılım seviyesinden bağımsız olarak karar sonuçlarına olan memnuniyeti etkilemektedir (Driscoll, 1978: 58).

\section{3. Örgütsel Özdeşleşme}

Psikolojik ve sosyolojik bir kavram olarak kullanılan özdeşleşme terimi, diğer insanlarla oluşan duygusal bağın rehberlik ettiği ve benzer olma algııının oluştuğu süreç olarak tanımlanmaktadır (Tokgöz ve Seymen, 2013: 63). Özdeşleşme kavramının örgütsel alana ilk kez Asforth ve Mael (1989) tarafından taşındığı ve sosyal kimlik kuramı çalışmaları üzerine inşa ettikleri görülmektedir. Sosyal kimlik kuramı, kişilerin grup üyeliği yoluyla sosyal kimlik ve dolayısıyla bireysel kimlik kazandığını varsaymaktadır. Bu bakış iki ana varsayıma dayanmaktadır. Birincisi, çalışanların kendi öz saygılarını güçlendirmek için motive olmaları, ikincisi ise, kişilerin kategorilerini karşılaştırmaları ile kendi çevrelerini oluşturmak ve bu çevre içerisinde kendilerine bir yer tanımlamak için kullanmalarıdır (Turunç ve Çelik, 2010: 188). Yine aynı kurama göre, insanlar kendilerini ve diğerlerini organizasyon üyeliği, dini üyelik, cinsiyet ve akranlık gibi çeşitli sosyal kategoriler altında sınıflama eğilimindedirler. Burada gruba atfedilen temel değerler üye tarafından özümsenmektedir.

Örgütsel özdeşleşme, işgörenin örgütle birlik olması ve kendini örgüte ait hissetmesi (Mael ve Ashforth, 1992: 4), kendini çalışııs olduğu örgütün bir parçası olarak görmesi (Wiesenfeld vd.,2001: 215) ve örgütün genel norm ve uygulamaların içselleştirdiği bir süreç olarak tanımlanabilir (Wiesenfeld vd.,1999: 778). Bu bağlamda, örgütsel özdeşleşme, işgörenin üyesi olduğu örgütün özellikleri üzerinden kendisini ne ölçüde tanımladığını anlatmaktadır(Dutton vd., 1994: 239-240).

Tokgöz ve Seymen, (2013: 63) özdeşleşmenin algısal ve bilişsel bir kavram olduğunu belirtirken, işgörenlerin örgütleriyle özdeşleşmelerinin onların örgütleriyle aralarındaki temel bağlantı görevini gören psikolojik bir alan (O’Reilly ve Chatman, 1986: 494) olarak değerlendirmektedirler. Dolayısıyla, örgütsel özdeşleşme örgütteki birçok önemli tutum ve davranışı etkileme özelliğine sahip bir kavram olarak karşımıza çıktı̆̆ı söylenebilir.

Diğer taraftan, Albert vd.,(2000) özdeşleşme ile ilgili olarak iki farklı güçten söz etmektedirler. Bunlardan ilki, bireyin kendini konumlandırma ihtiyacını tatmin etme arzusundan kaynaklanan güçtür. Bu durumda, her bireyin öncelikle biz kimiz sorusuna yanıt vermesi ve aynı zamanda diğer bireylerle etkin bir etkileşim sağlamak için onlar kim sorusunu sorması gerekli olmaktadır. íkinci güç ise, özdeşleşmenin bireyin kimliğini oluşturucu ve bütünleştirici yapısından kaynaklanmaktadır.

\subsection{Paternalist Liderlik ve Lidere Güven İlişkisi}

Güven olgusu üzerinde ilgili alan yazında kabul gören 3 temel yön bulunmaktadır. Bu temellerden ilki güvenilen tarafın davranışlarının kontrol edilemediği durumlarda güvenin gerçekleşmesi, ikincisi güvenen tarafın çıktılarının güvenilen tarafın davranışlarından etkilenecek düzeydeki bağımlıı̆ı ve son olarak güvenilen tarafın yardımsever (benevolently) şekilde hareket edeceğine dair güvenen tarafın inancı ya da beklentisidir (Whitener vd. 1998: 513). Mayer ve Gavin (2005) çalışmalarında yöneticinin yardımseverliği (benevolence) ve dürüstlüğü (integrity) yöneticiye duyulan güven seviyesini pozitif yönde etkilediğini bulgulamışlardır. Güven niyetinin oluşabilmesi için güvenilen tarafın yardımsever olacağı (benevolence belief) ve dürüst olacağı (honesty belief) inancı önemli bir etkendir (McKnight vd., 1998: 479-480).

Kişinin davranışlarını temelden etkileyen güven gibi psikolojik bir unsurun, lider üye etkileşimi içerisindeki yeri tartışılması gereken bir konudur. Nitekim, lidere olan güvenin önemi araştırmacılar tarafından yıllar içerisinde geniş şekilde ortaya konmuş ve çeşitli iş davranış ve tutumlarıyla olan bağı kurulmuştur (Ötken ve Cenkçi, 2012: 
526). Ancak, Paternalizm olgusu içerisinde lider üye etkileşiminin psikolojik yönünü araştıran çalışmaların sayısı oldukça azdır (Chen vd., 2014: 797). Pellegrini ve Scandura (2006) yardımseverlik, doğruluk ve dürüstlüğün paternalist liderlik özelliklerini oluşturan önemli faktörler olduğunu belirtmektedirler. Brown vd. (2005) çalışmalarında, dürüstlük (doğru söyleyen), doğruluk (ilkeli davranan), güvenilirlik (güvenilebilir, yardımsever) özellikleri ile karakterize etmiş oldukları etik liderlik ile lidere olan duygusal güven arasında olumlu yönde ilişki bulmuşlardır. Yine bu sonuçla paralel olarak, Shoorman vd. (2007) yapmış oldukları betimleyici çalışmada, yardımseverlik ve dürüstlük gibi faktörlerin astların üstlerine karşı güvenini olumlu yönde etkilediğini belirtmişlerdir. Ayrıca, Mishra (1996) güveni oluşturan kaygılanma (Colquitt vd., 2007: 913-921), doğruluk ve güvenilirlik boyutlarııı sırasıyla paternalist liderliğin yardımseverlik ve ahlak boyutlarına karşılık geldiğini ifade etmiştir. Wu vd.'nin (2012) görgül çalışmasında, paternalist liderliğin otoriterlik ve ahlak boyutlarının lidere olan güveni doğrudan etkilediğini, ancak otoriterlik boyutuyla güven arasındaki etki yönünün negatif olduğunu göstermişlerdir. Yine aynı çalışmada, yardımsever liderliğin, etkileşimsel adalet algısı üzerinden lidere olan güveni arttırdığını belirtmişlerdir.

Öte yandan, Dirks ve Ferrin (2001) liderin astlarına yönelik davranışının, onların lidere karşı olan güvenlerini doğrudan etkilediğini ifade etmektedirler. Çünkü işgörenlerin liderlerine olan güvenleri, onların davranışlarını güvenilir olarak değerlendirmelerine bağlıdır (Wu vd.,2012: 99). Paternalist liderlerin davranışları ile güven arasındaki ilişkiyi gösteren araştırmalarda, ahlaki ve yardımseverlik boyutlarının lidere güven ile pozitif; otoriterlik boyutu ile negatif ilişki içinde olduğu görülmektedir (Wu vd.,2012; Chen vd.,2014). Göncü vd.'nin (2014) araştırmalarında ise, tek boyutlu olarak ölçülen paternalist liderliğin güven ve özdeşleşme ile pozitif ilişkili olduğu bulunmuştur.

\subsection{Lidere Güven ve Örgütsel Özdeşleşme İlişkisi}

Liderler/amirler genellikle örgütte daha deneyimli kişilerdir ve örgütlerin onaylı temsilcileri olmalarından dolayı örgütün değerlerini simgelemektedirler (Schaubroeck vd., 2013: 1153). Bu nedenle liderle/amirle etkileşim içerisindeki bireyler örgütleriyle daha fazla psikolojik bağ kurmaktadırlar (Schaubroeck vd. 2013: 1153). İşgörenler örgütlerine ve liderlerine güven duydukça özdeşleşme bağlarını daha kolay oluştururlar (Deconinck, 2011: 620). Edwards ve Cable (2009) örgütsel özdeşleşmenin öncülleri arasında güven olgusunun yattığııı iddia etmektedirler. Restubog vd. (2008) üç ayrı modelde örgütsel güvenin psikolojik sözleşme ihlali ve örgütsel özdeşleşme arasında aracılık rolü oynadığını vurgulamaktadırlar. DeConinck (2011: 621) satış elemanlarının amirlerine duydukları güvenin artması halinde, bunun örgütleriyle özdeşleşme düzeylerini olumlu etkileyeceğini belirlemiş̧tir. Diğer bir çalışma bulgularına göre, örgüte yeni katılan işgörenlerin liderlerine olan duyuşsal ve bilişsel güvenleri örgütsel özdeşleşmelerini olumlu etkilemektedir (Schaubroeck vd., 2013: 1161).

\subsection{Paternalist Liderlik ve Örgütsel Özdeşleşme İlişkisi}

Giray ve Şahin (2014) gerçekleştirdikleri çalışmada yetkeci liderliğin duygusal bağlılık arasında negatif bir ilişki tespit etmişlerdir. Zhu vd. (2015) dürüst, güvenilir, adil ve ilgi gösteren özellikleri ile tanımladıkları etik liderliğin örgütsel özdeşleşmeyi etkilediğini ifade etmişlerdir. Bu özelliklerin paternalist liderliğin ahlaki bütünlüğü içerisinde düşünülmesi sebebiyle paternalist liderliğin ahlak boyutunun örgütsel özdeşleşmeyi geliştirdiği düşünülmektedir.

Paternalist liderliğin ikinci düzeyde ele alındığı bir çalışmada, örgütsel özdeşleşme ile arasında pozitif anlamlı bir ilişki olduğu tespit edilmiştir (Göncü vd., 2014). Benzer şekilde, diğer çalışmalarda paternalist liderliğin üç boyutunun örgütsel özdeşleşme üzerinde anlamlı etkilerinin olduğunu belirtilmektedir (Liu vd., 2010; Kim ve Jin, 2013). Bir başka çalışmada, örgütsel özdeşleşme ile paternalist liderliğin yardımseverlik ve ahlak boyutları arasında pozitif; otoriterlik boyutu ile negatif bir ilişkinin var olduğu saptanmıştır (Cheng ve Wang, 2015).

Paternalist liderlik ile örgütsel özdeşleşme arasındaki ilişkide lidere güvenin bir aracılık etkisinden söz edebilmek için oluşturulacak yapısal eşitliklerde Baron ve Kenny'nin (1986:1177) önerdiği 3 koşulun sağlanması gereklidir. Birinci koşul, birinci eşitlikte bağımsız değişkenin aracı değişkeni etkilemesi gereklidir. İkinci koşul, ikinci eşitlikteki bağımsız değişkenlerin bağımlı değişken üzerinde bir etkisinin olmasıdır. Üçüncü ve son koşul ise, üçüncü eşitlikteki aracı değişkenin bağımlı değişkeni etkilemesidir. Eğer bu tüm koşullar sağlanırsa 3. eşitlikteki bağımsız değişkenin bağımlı değişken üzerindeki etkisinin 2 eşitliktekinden daha az olması durumunda bir 
aracılık etkisinden söz etmek olasıdır. Buradan hareketle, yukarıdaki kuramsal açıklamalar ışığında aşağıdaki hipotezler geliştirilebilir:

H1: Paternalist liderlik boyutlarından yardımseverlik boyutu ile örgütsel özdeşleşme ilişkisinde lidere güvenin aracılık etkisi vardır.

H2: Paternalist liderlik boyutlarından ahlak boyutu ile örgütsel özdeşleşme ilişkisinde lidere güvenin aracılık etkisi vardır.

H3: Paternalist liderlik boyutlarından otoriterlik boyutu ile örgütsel özdeşleşme ilişkisinde lidere güvenin araclık etkisi vardır.

Yukarıda belirtilen çalışmanın amacı doğrultusunda ve kuramsal açıklamalar ışığında, Şekil 1'de gösterilen şematik araştırma modeli oluşturulmuştur. Modele göre, paternalist liderlik boyutlarının lidere güven üzerinden örgütsel özdeşleşmeyi yordayacağı düşünülmektedir. Diğer bir ifade ile modelde, paternalistik liderlik boyutlarını örgütsel özdeşleşme üzerine etkisinde lidere güvenin aracılık rolü oynadığı görülmektedir.

\section{Şekil 1: Araştırma Modeli}

\section{Paternalist Liderlik}

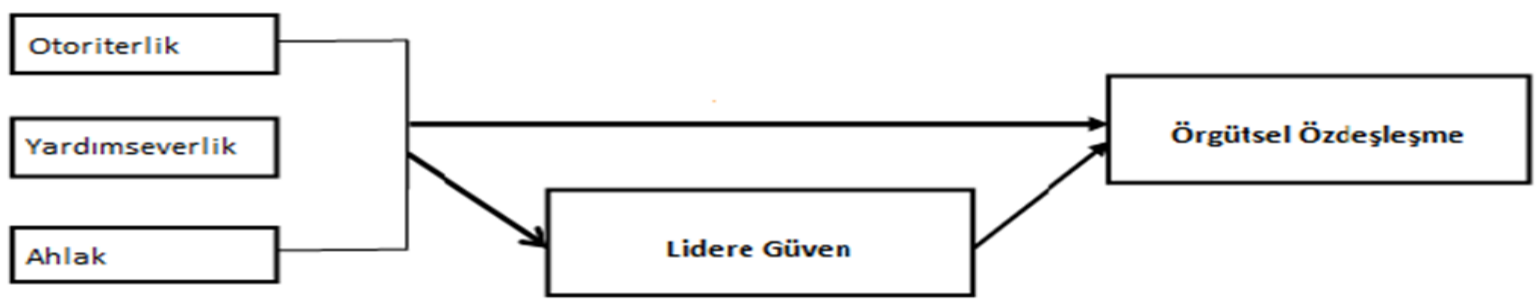

\section{VERI VE METODOLOJi}

Nesnelci bakış açısıyla "açıklayııı" bir çalışma olarak tasarımlanan bu çalışmada survey yöntemi kullanılmıştır. Araştırma verilerinin elde edilmesinde yapılandııımış soru formundan yararlanılmıştır. Soru formu, toplam 47 maddeden oluşmaktadır. 8 madde katılımcıların demografik özelliklerini belirlemek üzere hazırlanmıştır. Araştırma değişkenlerinden paternalist liderliği ölçmek üzere, Cheng vd. '’nin (2004) üç boyutlu ve 26 maddeden oluşan ölçeğinden, işgörenin lidere olan güvenini ölçmek üzere Robinson ve Rousseau'nun (1994) 7 maddeli tek boyutlu ölçeğinden, örgütsel özdeşleşme için ise, Mael ve Asforth'un (1992) 6 maddelik tek boyutlu ölçeğinden yararlanılmıştır. Anket formundaki ölçekler (1) Kesinlikle Katılmıyorum'dan...... (5) Kesinlikle Katılıyorum'a doğru olumsuzdan olumluya doğru 5'li Likert tipi ölçek düzenindedir. Araştırma verileri örneklem çerçevesini i̇zmir ilinde üç farklı sektörde faaliyette bulunan 198 firma çalışanı oluşturmuş ve kolayda örnekleme yöntemi kullanılmıştır. Ancak 50 katılımcının yanıtları eksik olması nedeniyle analize katılmamış, toplam 148 adet katıımcıdan elde edilen veriler analizlerde kullanılmıştır. Katııımcıların demografik özelliklerini gösteren bulgular Tablo 1'de sunulmuştur. Tablo $1^{\prime}$ den, katılımcıların cinsiyet dağılımları incelendiğinde katııımcıların büyük bölümünün (\%70.3) erkek oldukları gözlemlenmektedir. Eğitim durumlarının ise, ağırlıkı Lisans ve üzeri bir dereceye sahip kişilerden oluştukları anlaşılmaktadır. Katılımcıların \% 43.9'u 30 yaşın altında genç çalışanlardan \%41.2'si ise orta yaş grubuna dahil oldukları görülmektedir. Öte yandan, katılımcıların çoğunluğunun (\%60.1) evli ve büyük kısmının (\%81.1) 5 yıldan daha az bir süre ile kurumlarında çalıştıkları önemli bir bulgu olarak söylenebilir. 
Tablo 1: Katılımcıların Demografik Özellikleri

\begin{tabular}{|c|c|c|}
\hline Değişken Adı & Sıklık & $\begin{array}{c}\% \\
\text { (Yüzdesi) }\end{array}$ \\
\hline \multicolumn{3}{|l|}{ Cinsiyet } \\
\hline Erkek & 104 & 70.3 \\
\hline Kadın & 44 & 29.7 \\
\hline Belirtilmemiş & - & - \\
\hline \multicolumn{3}{|l|}{ Medeni Durum } \\
\hline Evli & 89 & 60.1 \\
\hline Bekar & 58 & 39.2 \\
\hline Belirtilmemiş & 1 & 0.7 \\
\hline \multicolumn{3}{|l|}{ Yaş } \\
\hline$<30$ & 65 & 43.9 \\
\hline $30-39$ & 61 & 41.2 \\
\hline $40-49$ & 18 & 12.2 \\
\hline $50-59$ & 3 & 2.0 \\
\hline 60 ve üzeri & - & - \\
\hline Belirtilmemiş & 1 & 0.7 \\
\hline \multicolumn{3}{|l|}{ Eğitim } \\
\hline Lise & 28 & 18.9 \\
\hline Ön Lisans & 14 & 9.5 \\
\hline Lisans & 68 & 46.0 \\
\hline Yüksek Lisans & 20 & 13.5 \\
\hline Doktora & 2 & 1.4 \\
\hline Diğer & 12 & 8.1 \\
\hline Belirtilmemiş & 4 & 2.7 \\
\hline \multicolumn{3}{|l|}{ Çalışma Yılı } \\
\hline 5 Yıl ve Daha $A z$ & 120 & 81.1 \\
\hline $6-10$ & 17 & 11.5 \\
\hline $11-15$ & 8 & 5.4 \\
\hline $16-20$ & 1 & 0.7 \\
\hline 21 Yıl ve Üzeri & 2 & 1.4 \\
\hline Belirtilmemiș & - & - \\
\hline
\end{tabular}

Ölçeklerin iç tutarlııklarını değerlendirmek üzere verilere güvenilirlik analizi, ardından faktöriyel yapılarını test etmek üzere veriler faktör analizi uygulanmıştı. Güvenilirlik analizi sonuçlarına göre, paternalist liderlik değişkeninin yardımseverlik, ahlak ve otorite boyutlarına ilişkin Cronbach Alfa değerleri sırasıyla $\alpha=, 915$, $\alpha=, 790, \alpha=0,822$ ve lidere güven değişkeninin $\alpha=, 858$ ve özdeşleşme değişkeninin ise $\alpha=, 888$ olarak bulunmuş ve değişkenlerin maddeleri arasında iç tutarıııı̆ın mevcut olduğu saptanmıştır. Güvenilirlik analizi bulgularına göre, paternalist liderliğin yardımseverlik boyutundan 1 madde, ahlak boyutundan 3 madde ve otoriterlik boyutundan 3 madde ve lidere güven değişkeninden ise 1 madde iç tutarlılı̆ı düşürdükleri için çıkarılmıştır.

Paternalist liderlik ölçek maddeleri faktör analizi sonucunda 3 boyutlu, lidere güven ve örgütsel özdeşleşmenin ise tek boyutlu oldukları saptanmıştır. Faktör analizi sonrası birden fazla faktörü niteleyen maddelerin çıkarılması sonucu kalan maddeler ve faktör yükleri Tablo 2'de gösterilmiştir. Paternalist liderliğe ilişkin KMO değeri $(, 879)$ Bartlett test değeri $(1360,183) p=, 000<, 05$ önem düzeyinde anlamlıdır. Toplam varyansı açıklama yüzdesi ise \%59.833'tür.Lidere güven değişkeninin faktör analizi sonucunun KMO değeri $(, 858)$ Bartlett test değeri $(605,628) \mathrm{p}=.000<, 05$ önem düzeyinde anlamlıdır. Toplam varyansı açıklama yüzdesi ise $\% 70,630^{\prime}$ dur. Örgütsel özdeşleşme değişkeninin faktör analizi sonucuna göre KMO değeri $(, 815)$ ve Bartlett test değeri $(486,763) p=, 000<, 05$ önem düzeyinde anlamlıdır. Toplam varyansı açıklama yüzdesi \%65,060'tır. Daha sonra, temel bileşenler analizinin ürettiği faktör yapılarını doğrulamak için doğrulayıcı faktör analizi yapılmış ve doğrulayıcı faktör analizi sonuçları temel bileşenler analizinin ürettiği faktör yapılarını desteklemiştir. 
Tablo 2: Temel Bileşenler Analizine Göre Değişkenlerin Faktör Yükleri(n=148)

\begin{tabular}{|c|c|c|c|c|c|}
\hline \multirow{2}{*}{ Madde } & \multicolumn{3}{|c|}{ Faktōr } & \multirow{2}{*}{1} \\
\hline & 1 & 2 & 3 & & \\
\hline Y3 &, 822 & & & & \\
\hline Y4 &, 786 & & & & \\
\hline Y2 &, 777 & & & & \\
\hline Y1 &, 740 & & & & \\
\hline Y10 &, 727 & & & & \\
\hline Y7 &, 708 & & & & \\
\hline Y9 &, 691 & & & & \\
\hline Y11 &, 668 & & & & \\
\hline Y8 &, 654 & & & & \\
\hline Y5 &, 603 & & & & \\
\hline O5 & &, 739 & & & \\
\hline O7 & &, 736 & & & \\
\hline O9 & &, 709 & & & \\
\hline O6 & &, 690 & & & \\
\hline O4 & &, 645 & & & \\
\hline O2 & &, 627 & & & \\
\hline A5 & & &, 842 & & \\
\hline A6 & & &, 774 & & \\
\hline A4 & & &, 659 & & \\
\hline G3 & & & &, 911 & \\
\hline G4 & & & &, 840 & \\
\hline G5 & & & &, 834 & \\
\hline G2 & & & &, 834 & \\
\hline G1 & & & &, 833 & \\
\hline G6 & & & &, 783 & \\
\hline Oz2 & & & & &, 859 \\
\hline Oz1 & & & & &, 845 \\
\hline Oz4 & & & & &, 838 \\
\hline Oz3 & & & & &, 819 \\
\hline Oz5 & & & & &, 778 \\
\hline Oz6 & & & & &, 687 \\
\hline
\end{tabular}

Y: yardımseverlik, O: otoriterlik, A: ahlak, G: güven, Oz: özdeşleşme

\section{BULGULAR}

Araştırmanın amacı doğrultusunda öncelikle verilerin iç tutarlılıkları ve faktöriyel yapısını belirlemek üzere veriler güvenilirlik ve faktör analizine tabi tutulmuş, daha sonra oluşturulan araştırma modeli ve hipotezleri test etmek üzere tanımlayıcı istatistikler (ortalama, standart sapma), korelasyon analizi ve yapısal eşitliklerin çözümlenmesi için path (yol) analizi uygulanmıştır. Bu analizlerin uygulanmasında SPSS 20 ve Lisrel 8.1 paket programlarından faydalanılmıştır.

Aşağıdaki Tablo 3 değişkenler ve değişkenlere ilişkin boyutların tanımlayıcı istatistikleri, korelasyon katsayıları ve Cronbach Alpha katsayılarını göstermektedir. Buna göre, paternalist liderlik boyutlarından ahlaki liderlik boyutunun 3.76 aritmetik ortalama ile en yüksek değere sahip olduğu görülmektedir. Örgütsel güven ve örgütsel özdeşleşmeye ilişkin aritmetik ortalama değerlerinin ölçek ortalamasının üzerinde olduğu gözlenmektedir. Otokratik liderlik davranışının ölçek ortalamasının altında olması önemli bir bulgudur. Bu anlamda çalışanların amirlerinin paternalist liderlik boyutlarına yönelik davranışların yardımsever, ahlaki ve otoriter olmayan bir şekilde algıladıkları söylenebilir.

Öte yandan, değişkenler arası korelasyonlar incelendiğinde örgütsel özdeşleşme ve ahlaki liderlik arasında anlamlı bir ilişkinin olmadığı, ancak yardımseverlik boyutu ile pozitif ve otokratik liderlik boyutu ile negatif anlamlı bir ilişki olduğu Tablo 3'ten anlaşılmaktadır.

Örgütsel güven değişkeni ile otokratik liderlik dışındaki tüm değişkenler arasında pozitif anlamlı bir ilişki olduğu, otokratik liderlik ile ilgili ise negatif anlamlı bir ilişki olduğu bulgulanmıştır.

Diğer taraftan, paternalist liderlik boyutlarının kendi aralarındaki korelasyonlar incelendiğinde otokratik liderliğin ahlak ve yardımseverlik boyutu ile negatif ilişkili; ahlak ve yardımseverlik boyutları arasında ise pozitif anlamlı ilişkili oldukları saptanmış, ancak bu ilişkinin çok güçlü olmadığı, dolayısıyla boyutlar arasından çoklu bağlantı sorunundan bahsedilemeyeceği söylenebilir. 
Tablo 3: Değişkenlere ilişkin tanımlayıcı istatistikler (Ortalama, Standart Sapma), Korelasyon ve Cronbach Alfa Katsayıları

\begin{tabular}{|c|c|c|c|c|c|c|c|}
\hline Değişkenler & Ortalama & $\begin{array}{l}\text { Standart } \\
\text { Sapma }\end{array}$ & 1 & 2 & 3 & 4 & 5 \\
\hline 1. Yardımseverlik & 3.4459 & .87109 & $(.915)$ & & & & \\
\hline 2.Ahlak & 3.7545 & 1.08003 &, $548^{\cdots}$ & $(.790)$ & & & \\
\hline 3.Otokratiklik & 2.3824 & .84794 &,$- 423^{\cdots}$ &,$- 392^{\cdots}$ & $(.822)$ & & \\
\hline 4.Örgütsel Güven & 3.7083 & .92102 &, $750^{\cdots}$ &, $613^{\cdots}$ &,$- 480^{\cdots}$ & $(.915)$ & \\
\hline $\begin{array}{l}\text { 5.Örgütsel } \\
\text { Özdeşleşme }\end{array}$ & 3.7162 & .82870 &, $308^{\cdots}$ & 151 &,$- 246 \cdots$ &, $277^{\cdots}$ & $(.888)$ \\
\hline
\end{tabular}

Çalışmanın amacı doğrultusunda Şekil 1'deki varsayımlanan yapısal eşitlik modeli test etmek üzere verilere yol (path) analizi uygulanmıştır. I. aşamada model bir bütün olarak test edildikten sonra Şekil 2'de görüldüğü gibi paternalist liderliğin otokratiklik boyutunun güven değişkenini yordamadığı anlaşılmıştır. Bu durum Baron ve Kenny'nin (1986) varsayımlarından birincisini ihlal etmektedir. Dolayısıyla, bu boyut modelden çıkarılarak model testi tekrarlanmalıdır (Şimşek, 2007:146).

\section{Şekil 2: Yardımseverlik, Ahlak ve Otokratiklik Tam Aracılık Modeli t Değerleri}

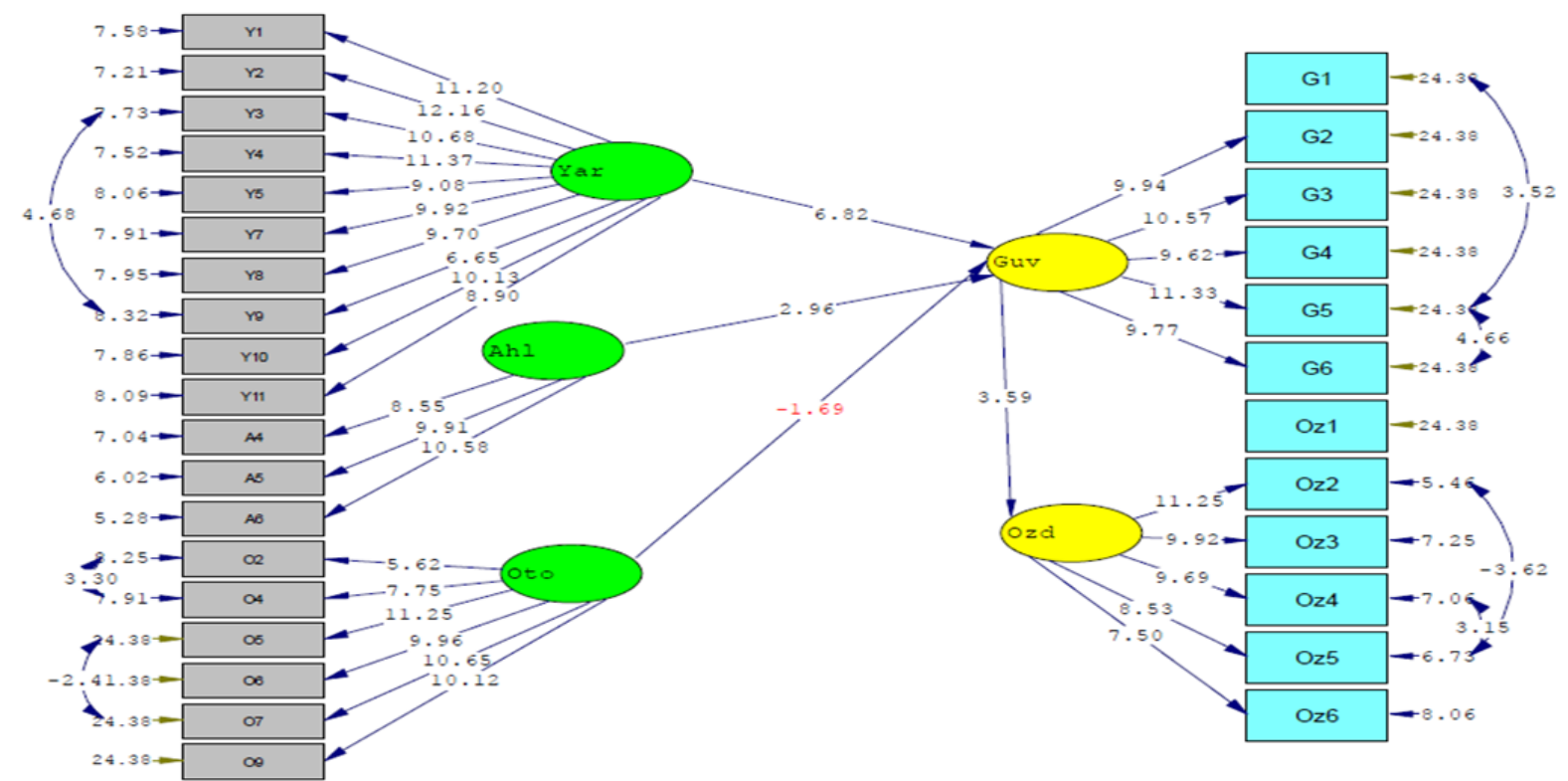

Chi-Square $=723.79, \mathrm{df}=430, \mathrm{P}$-value $=0.00000, \mathrm{RMSEA}=0.056$

II. aşamada, otoriterlik boyutu modelden çıkarılıp model tekrar test edildiğinde, yardımseverlik ve ahlak boyutlarının güven ile anlamlı ilişkili olduğu ve güven değişkeninin de özdeşleşme ile anlamlı bir ilişkisi olduğu Şekil 3'te görülmektedir. Buradan hareketle Baron ve Kenny'nin (1986) ikinci varsayımının sağlanıp sağlanmadığını teyit etmek için aracılık etkisinde olan güven değişkeni kaldırılarak ahlak ve yardımseverlik boyutlarının doğrudan etkileri incelenmelidir (Şimşek, 2007:147). 


\section{Şekil 3: Yardımseverlik ve Ahlak Tam Aracılık Model Testi (Korelasyon ve T Değerleri)}
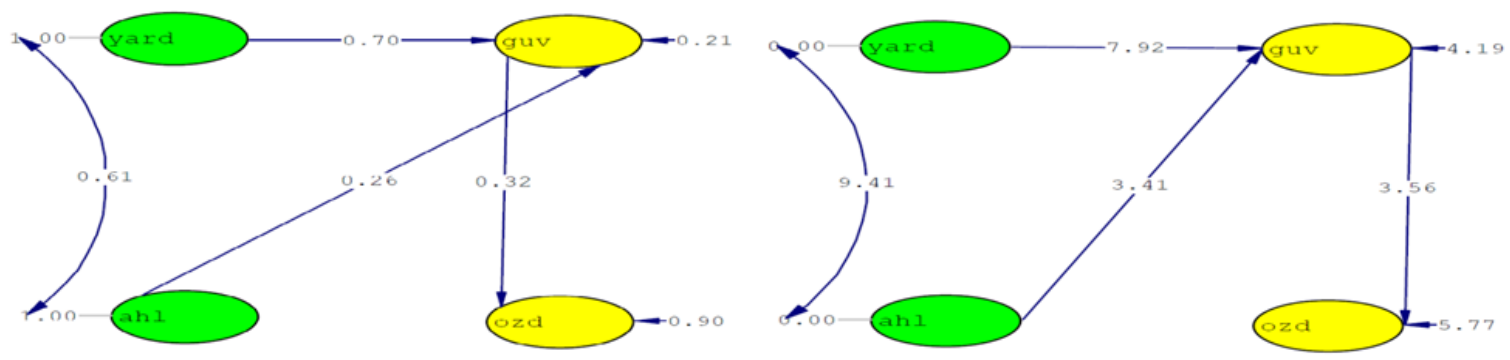

Chi-Square $=410.84, \mathrm{df}=270, \mathrm{P}$-value $=0.00000, \mathrm{RMSEA}=0.060$

III.aşamada, yardımseverlik boyutunun örgütsel özdeşleşme değişkeni arasında anlamlı bir ilişki olduğu gözlenmesine karşın ahlak boyutu ile özdeşleşme arasında anlamlı bir ilişki olmadığı bulgusuna rastlanmıştır. Dolayısıyla Baron ve Kenny'nin (1986) koşuluna göre ahlak boyutu için bir aracılık ilişkisi olmadığı Şekil 4'teki t değerlerinden anlaşılmaktadır. Buna bağıı olarak, ahlak boyutu modelden çıkarılarak, yardımseverlik boyutunun örgütsel özdeşleşme ile ilişkisinde güvenin aracılık rolünü belirlemek için süreç baştan tekrarlanmalıdır.

\section{Şekil 4: Yardımseverlik ve Ahlak Boyutlarının Özdeşleşme Üzerindeki Doğrudan Etkileri (Korelasyon ve T Değerleri)}
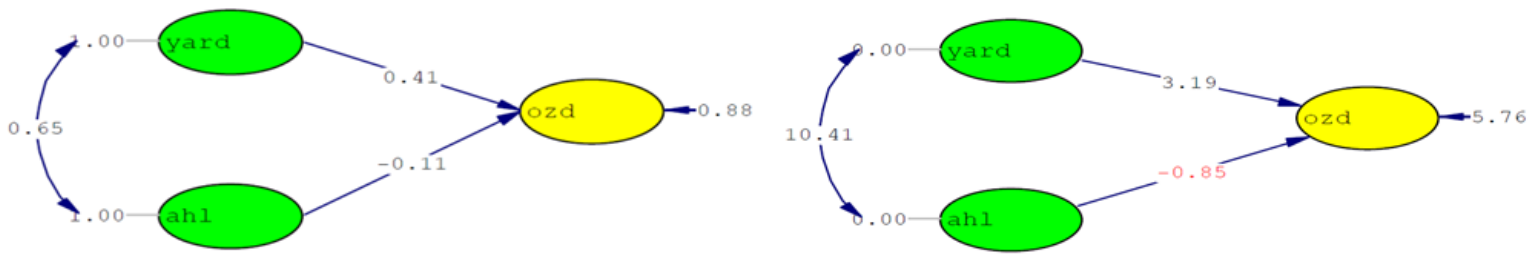

Chi-Square $=233.45, \mathrm{df}=146, \mathrm{P}$-value $=0.00001, \mathrm{RMSEA}=0.064$

Bu doğrultuda Şekil 5, yardımseverlik boyutunun örgütsel özdeşleşme üzerine etkisinde güven değişkeninin aracılık rolü oynadığı izlenimi vermektedir. Ancak söz konusu aracılık rolünü ortaya koyabilmek için, yardımseverliğin örgütsel özdeşleşme üzerindeki doğrudan etkisini de test etmek gerekecektir. Bu durum, Baron ve Kenny'nin (1986) ikinci koşulunu test etmek açısından önem taşımaktadır.

\section{Şekil 5: Yardımseverlik Tam Aracılık Testi (Korelasyon ve T Değerleri)}
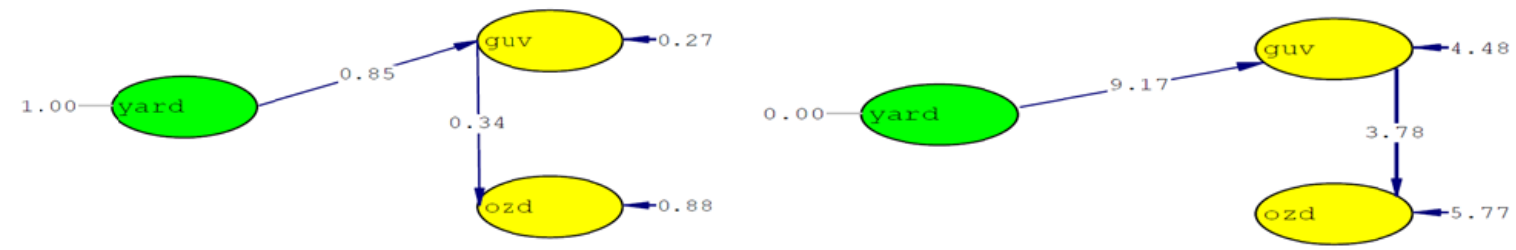

Chi-Square $=258.04, \mathrm{df}=200, \mathrm{P}$-value $=0.00353, \mathrm{RMSEA}=0.044$

Şekil 6, yardımseverlik boyutu ile örgütsel özdeşleşme arasında anlamlı bir ilişki olduğunu bulgulamaktadır. Bu sonuç bir aracılık etkisi olduğunu göstermektedir. Fakat bu etkinin tam aracılık mı yoksa kısmi aracılık mı olduğunu belirlemek için kısmi aracılık testi gerçekleştirilmiştir.

Şekil 6: Yardımseverliğin Özdeşleşme Üzerindeki Doğrudan Etkisi (Korelasyon ve T Değerleri)
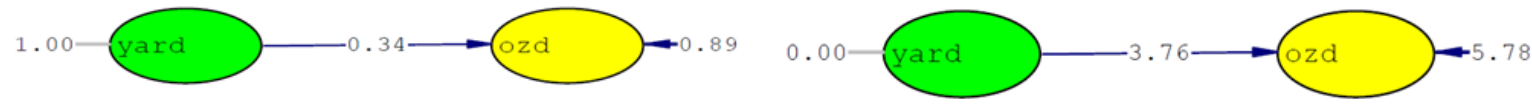

Chi-Square $=153.31, \mathrm{df}=100, \mathrm{P}$-value $=0.00049, \mathrm{RMSEA}=0.060$ 
Şekil 7'de gösterilen kısmi aracılık testi sonuçlarına göre, güven aracılık rolünde iken yardımseverlik ve örgütsel özdeşleşme arasındaki doğrudan etkisi düşmekte ve anlamsızlaşmaktadır. Bu durum Baron ve Kenny'nin (1986) tüm koşullarını sağlandığını gösteren bir bulgudur. Tüm bu analizler ışığında, yardımseverlik ile özdeşleşme ilişkisinde güvenin tam aracılık rolünde olduğu söylenebilir.

Şekil 7: Yardımseverlik ile Özdeşleşme Etkisinde Güvenin Kısmi Aracılık Testi (Korelasyon ve T Değerleri)
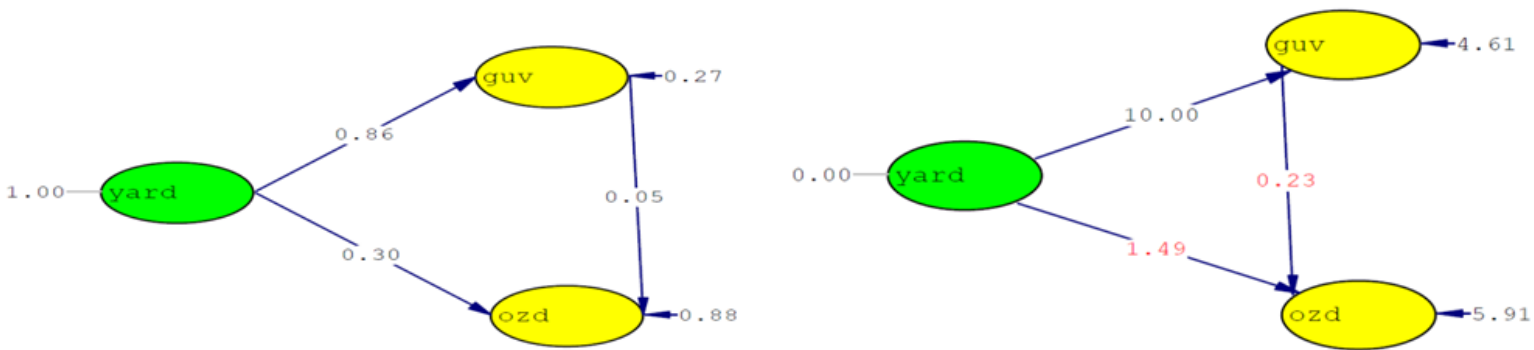

Bu bağlamda, analiz sonucu elde edilen model gözlenen değişkenlerle birlikte şekil 8'deki gibi gösterilebilir.

Şekil 8: Yardımseverlik ile Özdeşleşme iliş̧kisinde Güvenin Tam Aracılık Rolü (Gözlenen Değişkenler Dahil Model)

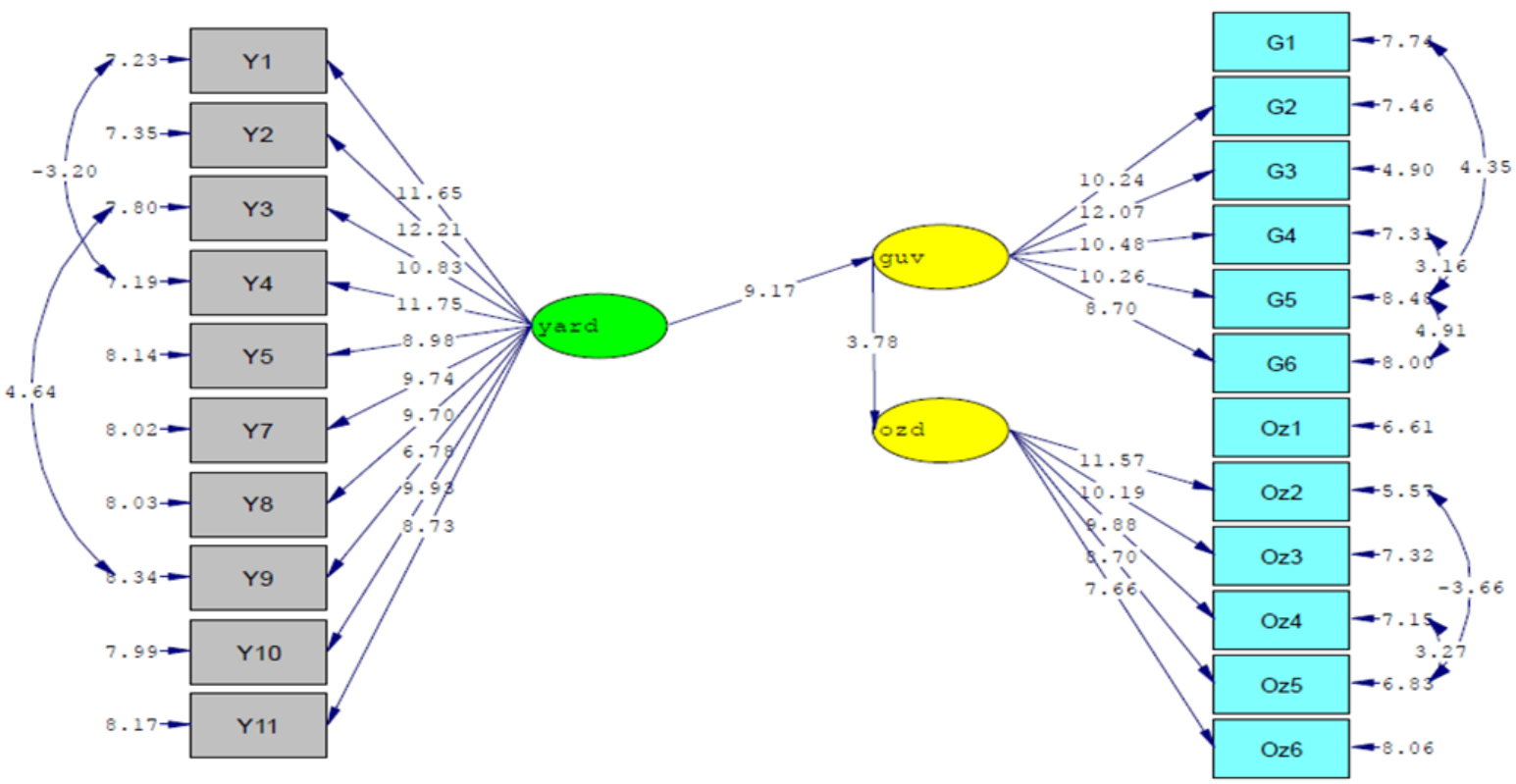

Modelin uyum iyiliği değerleri Tablo 4'te verilmektedir. Uyum iyiliği değerlerinin çok yüksek olduğu ve modelin anlamlı olduğu gözlenmektedir. 
Tablo 4: Modellerin Uyum İyiliği Değerleri

\begin{tabular}{|c|c|c|c|}
\hline indis & Model 4 & $\begin{array}{c}\text { Olması } \\
\text { Gereken }\end{array}$ & Sonuc \\
\hline $\mathrm{X}^{2} / \mathrm{df}$ & $\mathbf{1 . 2 9 0 2}$ & $<2$ & Iyi Uyum \\
\hline GFI & $\mathbf{0 . 8 6}$ & $>0.90$ & Kabul Edilebilir Uyum \\
\hline AGFI & $\mathbf{0 . 8 3}$ & $>0.90$ & Kabul Edilebilir Uyum \\
\hline CFI & $\mathbf{0 . 9 9}$ & $>0.90$ & Iyi Uyum \\
\hline IFI & $\mathbf{0 . 9 9}$ & $>0.90$ & lyi Uyum \\
\hline RMSEA & $\mathbf{0 . 0 4 4}$ & $<0.05$ & Iyi Uyum \\
\hline RMR & $\mathbf{0 . 0 5 7}$ & $<0.05$ & Kabul Edilebilir Uyum \\
\hline Crictical N & $\mathbf{1 2 9 . 4 4}$ & $<148$ & Iyi Uyum \\
\hline NNFI & $\mathbf{0 . 9 8}$ & $>0.90$ & Iyi Uyum \\
\hline NFI & $\mathbf{0 . 9 5}$ & $>0.90$ & iyi Uyum \\
\hline
\end{tabular}

\section{SONUÇ}

Bu çalışma, paternalist liderlik ile örgütsel özdeşleşme ilişkisinde lidere güvenin aracılık etkisini ortaya koymayı amaçlamıştır. Bulgular, paternalist liderliğin yardımseverlik boyutu ile örgütsel özdeşleşme ilişkisinde lidere güvenin tam aracılık rolü olduğunu göstermiştir. Yardımsever liderlik davranışı, astlarına sadece işinde değil, özel hayatında da ilgisini esirgemeyen ve astlarıyla ilişkilerinde belirli ahlaki standartlara sahip bir liderlik anlayışını ifade etmektedir. Bu tip bir liderlik davranışı doğrudan astların özdeşleşmelerine yol açabildiği gibi, astların liderlerine karşı güven yarattığı, dolayısıyla güven üzerinden örgütleri ile özdeşleşmelerini daha da güçlendirdiği söylenebilir. Öte yandan, paternalist liderliğin diğer iki boyutunun lidere güven üzerinden örgütsel özdeşleşmeyi açıklamadığı görülmüştür.

Özellikle paternalist liderlik boyutlarından ahlaki liderlik ile örgütsel özdeşleşme arasında doğrudan bir ilişki bulgulanamamıştır. Ancak ahlaki liderliğin güven üzerinde pozitif bir etkisi görülmektedir. Diğer bir ifade ile, ahlaki liderlik davranışının astlarda liderlerine yönelik bir güven oluşturduğu ancak örgütlerine aitlik oluşumunda yetersiz kaldığı anlaşılmaktadır. Ahlaki liderlik davranışı ile lidere güven ilişkisi astların üstleri ile bireysel düzeydeki etkileşimlerine dayanmaktadır. Bu bağlamda, astların amirlerinin ahlaki standartlara ve değer yargılarına göre davranışlar sergilediği algısı, amirlerinin astlarının zaafiyetinden yararlanmayacağı düşüncesi ile birlikte amirine güven oluşumunu etkilemesi doğal bir sonuçtur. Diğer bir anlatımla, ahlaki liderlik davranışları daha çok kişilik özellikleri ile bağıntılı olduğundan dolayı bir yandan bireye güveni şekillendirirken diğer yandan birey, grup ve örgüt düzeyinde farklı özdeşleşme seviyelerine yol açabilir.

Otoriter liderlik davranışı ile örgütsel özdeşleşme ve lidere güven arasında negatif bir ilişki tespit edilmiş ancak, bu liderlik davranışının lidere güven üzerinden örgütsel özdeşleşmeyi açıklamadığı saptanmıştır. Bu sonuca, bu tip liderlik davranışlarının genellikle astların kayıtsız bir şekilde emirlere uyması, karar ve amaçlara katııımına olanak tanımamasının neden olduğu söylenebilir. Bireyci kültürlerinde görülebilecek bu sonuç küreselleşme, ulaşım ve iletişim teknolojileri sayesinde kültürlerarası etkileşimin artmasının doğal bir sonucu olarak açıklanabilir. Bu gelişmelerin sonucunda toplumlar değişim gösterebilmektedir. Bu noktada üzerinden uzun yıllar geçmiş araştırma bulgularına dayalı kültürel sınıflamaların günümüz koşullarında yinelenmesinde yarar vardır. Böylece doğu ve batı toplumlarının kültürel özelliklerinde yakınlaşma ya da uzaklaşma bağlamında ne ölçüde bir değişimin olduğunu görmek mümkün olacaktır.

Bu çalışmanın sonuçları örneklemi çerçevesinde değerlendirilmelidir. Daha geniş örneklemlerle araştırma modelinin sınanması, modelin geçerliliği ve genelleme yapabilme bakımından yerinde olacaktır. Bunun yanında araştırmacılar gelecekte, paternalist liderlik ile özdeşleşme ilişkisinde lidere güven yanında, yönetime güven, iş arkadaşlarına güven gibi diğer güven türlerini ara veya düzenleyici değişken olarak değerlendirebilirler. Ayrıca paternalist liderliğin iş doyumu, işten ayrılma niyeti, iyi olma hali gibi başka örgütsel davranış çıktıları ile ilişkilendirilmesi alan yazına katkı sağlayacaktır. 


\section{KAYNAKÇA}

Ashforth, B. E. \& Mael, F. 1989, “Social Identity Theory and the Organization”, Academy of Management Review, vol. 14, no. 1, pp.20-39.

Albert, S., Ashforth, B. E. \& Dutton, J. E. 2000, "Organizational Identity and Identification: Charting New Waters and Building New Bridges", Academy of Management Review, vol. 25, no. 1, pp.13-17.

Aycan, Z. 2006, "Paternalism: Towards Conceptual Refinement and Operationalization", Yang, K.S., Hwang, K.K., \& Kim, U. (Der.), Scientific Advances in Indigenous Psychologies: Empirical, Philosophical, and Cultural Contributions (pp.445-466), London: Cambridge University Press.

Aycan, Z., Kanungo, R., Mendonca, M., Yu, K., Deller, J., Stahl, G., \& Kurshid, A. 2000, "Impact of Culture on Human Resource Management Practices: A 10-Country Comparison", Applied Psychology, vol. 49, no. 1, pp.192-221.

Aycan, Z., \& Kabasakal, H. 2006, "Social Contract and Perceived Justice of Workplace Practices to Cope with Financial Crisis", Group \& Organization Management, vol. 31, no. 4, pp.469-502.

Baron, R. M., \& Kenny, D. A. 1986, “The Moderator-Mediator Variable Distinction in Social Psychological Research: Conceptual, Strategic, and Statistical Considerations", Journal of Personality and Social Psychology, vol. 51, no. 6, pp.1173-1182

Börekçi, D. Y. 2009, “Paternalist Leadership Style's Evolution in E-Culture”, İstanbul Üniversitesi İşletme Fakültesi Dergisi, vol. 38, no. 2, pp.103-109.

Brown, M. E., Treviño, L. K., \& Harrison, D. A. 2005, “Ethical Leadership: A Social Learning Perspective for Construct Development and Testing", Organizational Behavior and Human Decision Processes, vol. 97, no. 2, pp.117-134.

Bunker, B. B., Alban, B. T., \& Lewicki, R. J. 2004, "Ideas in Currency and OD Practice Has the Well Gone Dry?", The Journal of Applied Behavioral Science, vol. 40, no. 4, pp.403-422.

Burke, C. S., Sims, D. E., Lazzara, E. H., \& Salas, E. 2007, “Trust in Leadership: A Multi-Level Review and Integration", The Leadership Quarterly, vol. 18, no. 6, pp.606-632.

Chen, X. P., Eberly, M. B., Chiang, T. J., Farh, J. L., \& Cheng, B. S. 2014, “Affective Trust in Chinese Leaders Linking Paternalistic Leadership to Employee Performance", Journal of Management, vol. 40, no. 3, pp.796-819.

Cheng, B.S.,Chou, L.F., Wu, T. Y., Huang, M.P. \& Farh, J.L. 2004, “Paternalistic Leadership and Subordinate Responses: Establishing A Leadership Model in Chinese Organizations", Asian Journal of Social Psychology, vol. 7, no. 1, pp.89-117.

Cheng, M. Y., \& Wang, L. 2015, "The Mediating Effect of Ethical Climate on the Relationship Between Paternalistic Leadership and Team Identification: A Team-Level Analysis in the Chinese Context". Journal of Business Ethics, vol. 129, no. 3, pp.639-654.

Colquitt, J. A., Scott, B. A., \& LePine, J. A. 2007, "Trust, Trustworthiness, and Trust Propensity: A Meta-Analytic Test of Their Unique Relationships with Risk Taking and Job Performance", Journal of Applied Psychology, vol. 92, no. 4, pp.909-927.

Cook, J., \& Wall, T. 1980, "New Work Attitude Measures of Trust, Organizational Commitment and Personal Need Non-Fulfilment", Journal of Occupational Psychology, vol. 53, no. 1, pp.39-52.

Culbert, S. A. \& McDonough, J. J. 1986, "The Politics of Trust and Organization Empowerment", Public Administration Quarterly, vol. 10, no. 2, pp.171-188.

Deconinck, J. B. 2011, "The Effects of Ethical Climate on Organizational Identification, Supervisory Trust, and Turnover Among Salespeople", Journal of Business Research, vol: 64, no: 6, pp.617-624.

Dirks, K. T., \& Ferrin, D. L. 2001, “The Role of Trust in Organizational Settings”, Organization Science, vol. 12, no. 4, pp.450-467.

Dirks, K. T. 2000, “Trust in Leadership and Team Performance: Evidence from NCAA Basketball”, Journal of Applied Psychology, vol. 85, no. 6, pp.1004-1012.

Driscoll, J. W. 1978, "Trust and Participation in Organizational Decision Making as Predictors of Satisfaction", Academy of Management Journal, vol. 21, no. 1, pp.44-56.

Dutton, J. E., Dukerich, J. M., \& Harquail, C. V. 1994, “Organizational Images and Member Identification”, Administrative Science Quarterly, vol. 39 , no. 2 , pp.239-263.

Edwards, J. R. \& Cable, D. M. 2009, “The Value of Value Congruence”, Journal of Applied Psychology, vol. 94, no. 3, pp.654-677.

Erben, G. S. \& Ötken, A. B. 2014, “Paternalist Liderlik ve İşe Illişkin İyilik İlişkisinde İş-Yaşam Dengesinin Rolü”, Yönetim ve Ekonomi Araştırmaları Dergisi, vol: 22, pp.103-121.

Farh, J. L., \& Cheng, B. S. 2000, “A Cultural Analysis of Paternalistic Leadership in Chinese Organizations”, Tsui, A. S. ve Weldon, E. (Der.), Management and Organizations in the Chinese Context, pp.84-127, Great Britain: Macmillian Press LTD.

Gao, L., Janssen, O. \& Shi, K. 2011, "Leader Trust And Employee Voice: The Moderating Role of Empowering Leader Behaviors", The Leadership Quarterly, vol. 22, no. 4, pp.787-798. 
Gelfand, M. J., Erez, M., \& Aycan, Z. 2007, “Cross-Cultural Organizational Behavior”, Annu. Rev. Psychol., vol. 58, pp.479-514.

Giray, M. D. \& Şahin, D. N. 2014, “Liderlik Stillerinin Duygusal Bağlılık ve Işsten Ayrılma Niyetiyle illişkilerinde Örgütsel Destek Algııının Aracllık Rolü", Türk Psikoloji Dergisi, vol. 29, no. 73, pp.1-17.

Göncü, A., Aycan, Z., \& Johnson, R. E. 2014, "Effects of Paternalistic and Transformational Leadership on Follower Outcomes", International Journal of Management and Business, vol. 5, no. 1, pp.36-58.

Hosmer, L. T. 1995, "Trust: The Connecting Link Between Organizational Theory and Philosophical Ethics", Academy of Management Review, vol: 20, no. 2, pp.379-403.

Kim, J. \& Jin, Y. 2013, “The Effect of Paternalistic Leadership on Employees' Organizational Identification and Organization-based Selfesteem in Hotel Restaurant", Tourism Research, vol. 6, pp.103-122.

Köksal, O. 2011a, "Paternalizm ile Algılanan Örgütsel Adalet Arasındaki Ilişkinin Tespitine Yönelik Bir Araştırma", Cumhuriyet Üniversitesi i.i.B.F. Dergisi, vol. 12, no. 2, pp.159-170.

Köksal, O. 2011b, “Bir Kültürel Liderlik Paradoksu: Paternalizm”, Mustafa Kemal Üniversitesi Sosyal Bilimler Enstitüsü Dergisi, vol: 8, no: 15, pp.101-122.

Liu, Y., Zhang, J. \& Huang, G. 2010, "Paternalistic Leadership and Its Impact on Organizational Effectiveness", 260-266, IFERA 2010 Family Business Forum, Zhuhai, China.

Mael, F., \& Ashforth, B. E. 1992, "Alumni and Their Alma Mater: A Partial Test of The Reformulated Model of Organizational Identification", Journal of Organizational Behavior, vol. 13, no. 2, pp.103-123.

Mayer, R. C., Davis, J. H., \& Schoorman, F. D. 1995, “An Integrative Model of Organizational Trust”, Academy of Management Review, vol. 20, no. 3, pp.709-734.

Mayer, R. C., \& Gavin, M. B. 2005, "Trust in Management and Performance: Who Minds The Shop while The Employees Watch The Boss?", Academy of Management Journal, vol. 48, no. 5, pp.874-888.

Mccauley, D. P., \& Kuhnert, K. W. 1992, "A Theoretıcal Review and Empırıcal Investıgatıon of Employee Trust in Management", Public Administration Quarterly, vol. 16, no. 2, pp.265-284.

Mcknight, D. H., Cummings, L. L., \& Chervany, N. L. 1998, "Initial Trust Formation in New Organizational Relationships", Academy of Management Review, vol. 23, no.3, pp.473-490.

Mishra, A. K. 1996, "Organizational Responses to Crisis. Trust in Organizations", Frontiers of Theory and Research, pp.261-287. Sage Publication, California

https://www.google.com.tr/books?hl=tr\&lr=\&id=ddpyAwAAQBAJ\&oi=fnd\&pg=PP1\&dq=Organizational+responses+to+crisis.+Trust+in+Org anizations.\&ots=cpR6Xp0Eek\&sig=B2CbZoO10-HAIQ1z8kvmNSIY-

Pk\&redir_esc=y\#v=onepage\&q=Organizational\%20responses\%20to\%20crisis.\%20Trust\%20in\%200rganizations.\&f=false ） (Erişim Tarihi:25.03.2015)

Niu, C. P., Wang, A. C., \& Cheng, B. S. 2009, "Effectiveness of A Moral and Benevolent Leader: Probing The Interactions of The Dimensions of Paternalistic Leadership", Asian Journal of Social Psychology, vol. 12, no. 1, pp.32-39.

Oldham, G. R. 1975, "The Impact of Supervisory Characteristics on Goal Acceptance", Academy of Management Journal, vol. 18, no. 3, pp.461-475.

O'Reilly, C., \& Chatman, J. 1986, “Organizational Commitment and Psychological Attachment: The Effects of Compliance, Identification, and Internalization on Prosocial Behaviour", Journal of Applied Psychology, vol. 71, no. 3, pp.492-499.

Ötken, A. B., \& Cenkci, T. 2012, "The Impact of Paternalistic Leadership on Ethical Climate: The Moderating Role of Trust in Leader", Journal of Business Ethics, vol. 108, no. 4, pp.525-536.

Paşa, F.S., Kabasakal, H., \& Bodur, M. 2001, "Society, Organisations, and Leadership in Turkey", Applied Psychology, vol. 50 no.4, pp.559589.

Pellegrini, E. K. \& Scandura, T. A. 2008, “Paternalistic Leadership: A Review and Agenda for Future Research", Journal of Management, vol. 34, no. 3, pp.566-593.

Pellegrini, E. K., Scandura, T. A., \& Jayaraman, V. 2010, “Cross-Cultural Generalizability of Paternalistic Leadership: An Expansion of LeaderMember Exchange Theory", Group \& Organization Management, vol. 35, no. 4, pp.391-420.

Pillai, R., Schriesheim, C. A. \& Williams, E. S. 1999, "Fairness Perceptions and Trust as Mediators for Transformational and Transactional Leadership: A Two-Sample Study", Journal of Management, vol. 25, no. 6, pp.897-933.

Podsakoff, P. M., MacKenzie, S. B., \& Bommer, W. H. 1996, "Transformational Leader Behaviors and Substitutes for Leadership as Determinants of Employee Satisfaction, Commitment, Trust, and Organizational Citizenship Behaviors", Journal of Management, vol. 22, no. 2, pp.259-298. 
Restubog, S. L. D., Hornsey, M. J., Bordia, P., \& Esposo, S. R. 2008, “Effects of Psychological Contract Breach on Organizational Citizenship Behaviour: Insights from The Group Value Model", Journal of Management Studies, vol. 45, no.8, pp.1377-1400.

Rich, G. A. 1997, "The Sales Manager as A Role Model: Effects on Trust, Job Satisfaction, and Performance of Salespeople", Journal of the Academy of Marketing Science, vol. 25, no. 4, pp.319-328.

Robinson, S. L., \& Rousseau, D. M. 1994, "Violating the Psychological Contract: Not the Exception but the Norm", Journal of Organizational Behavior, vol. 15, no.3, pp.245-259.

Schaubroeck, J., Peng, A., \& Hannah, S. 2013, "Developing Trust with Peers and Leaders: Impacts on Organizational Identification and Performance During Entry", Academy of Management Journal, vol. 56, no. 4, pp.1148-1168.

Schoorman, F. D., Mayer, R. C., \& Davis, J. H. 2007, “An Integrative Model of Organizational Trust: Past, Present, and Future”, Academy of Management Review, vol. 32, no. 2, pp.344-354.

Şimşek, Ö. F., 2007, “Yapısal Eşitlik Modellemesine Giriş Temel İlkeler ve LISREL Uygulamaları”, Ekinoks Yayınları: Ankara

Turunç, Ö.,\& Çelik, M. 2010, "Algılanan Örgütsel Desteğin Çalışanların İş-Aile, Aile-iş̧ Çatışması, Örgütsel Özdeşleşme ve iş̧ten Ayrılma Niyetine Etkisi: Savunma Sektöründe Bir Araştırma", Atatürk Üniversitesi Sosyal Bilimler Enstitüsü Dergisi, vol. 14, no. 1, pp.209-232.

Tokgöz, E. \& Aytemiz Seymen, O. 2013, “Örgütsel Güven, Örgütsel Özdeşleşme ve Örgütsel Vatandaşlık Davranıı̧ı Arasındaki illişki: Bir Devlet Hastanesinde Araştırma”, Öneri Dergisi, vol. 10, no. 9, pp.61-76.

Wiesenfeld, B. M., Raghuram, S., \& Garud, R. 1999," Communication Patterns as Determinants of Organizational İdentification in A Virtual Organization", Organization Science, vol. 10, no.6, pp. 777-790.

Wiesenfeld, B.M.,Raghuram, S. \& Garud, R. 2001, “Organizational Identification among Virtual Workers: The Role of Need for Affiliation and Perceived Work-Based Social Support”, Journal of Management, vol. 27, no. 2, pp.213-229.

Whitener, E. M., Brodt, S. E., Korsgaard, M. A., \& Werner, J. M. 1998, "Managers as Initiators of Trust: An Exchange Relationship Framework for Understanding Managerial Trustworthy Behavior", Academy of Management Review, vol. 23, no. 3, pp.513-530.

Wu, M., Huang, X., Li, C., \& Liu, W. 2012, "Perceived Interactional Justice and Trust-in-supervisor as Mediators for Paternalistic Leadership", Management and Organization Review, vol. 8, no. 1, pp.97-121.

Yeh, H. R., Chi, H. K., \& Chiou, C. Y. 2008, "The Influences of Paternalistic Leadership, Job Stress, and Organizational Commitment on Organizational Performance: An Empirical Study of Policemen in Taiwan", The Journal of International Management Studies, vol. 3, no.2, pp.85-91.

Zhu, W., He, H., Treviño, L. K., Chao, M. M., \& Wang, W. 2015, "Ethical leadership and follower voice and performance: The role of follower identifications and entity morality beliefs". The Leadership Quarterly, vol. 26, no. 5, pp.702-718.

http://www.etimolojiturkce.com/kelime/peder. (Erişim Tarihi: 25.03.2015) 